\title{
Application of propolis in agriculture
}

\author{
Grimaldo Jorge Lemos de Carvalho ${ }^{1, * ~(D) ~ h t t p s: / / o r c i d . o r g / 0000-0002-9987-8459 ~}$ \\ Geni da Silva Sodré1 (D) https://orcid.org/0000-0002-6184-4720 \\ 1. Universidade Federal do Recôncavo da Bahia - Centro de Ciências Agrárias, Ambientais e Biológicas - Cruz das Almas (BA), Brazil. \\ *Corresponding author: grilec@ufrb.edu.br
}

\begin{abstract}
This work carried out a literary review of the different aspects related to the use of propolis in the management of plant crops and their advances in agriculture. Propolis is a product widely known for its therapeutic capacity. Due to its antimicrobial and antioxidant properties, among other biological activities, its use has been studied in agriculture. Studies they show that the use of propolis via ethanolic propolis extract (EEP) provides beneficial effects on crops. These benefits are associated with the control of phytopathogens, postharvest preservation and conservation of fruits and vegetables and promotion of plant growth. There is evidence that benefits are the result of the propolis chemical composition that is especially rich in phenolic compounds and nutrients. In addition, the typical waxy property of propolis results in an efficient biofilm in plant tissues. There are still scarce reports showing that the use of EEP in crop management controls the presence of insects and reduces water stress in plants. Generally, studies are mainly focused on in vivo and greenhouse evaluations, requiring further research to elucidate the full potential of the use of propolis in crop management.
\end{abstract}

Keywords: disease control; ethanolic propolis extract (EEP); phytosanitary; promotion of growth; pests.

Propolis is a gummy and resinous substance naturally produced by plants, that is collected by Apis mellifera bees in flower buds, sap flow, trichomes and other vegetable structures (GHISALBERTI, 1979; BANKOVA et al., 2002; BONAMIGO et al., 2017). In the hive, bees incorporate salivary secretions, wax and pollen to obtain the final chemical complex product (OLDONI et al., 2011).

More than 300 substances have already been identified in different types of propolis, especially flavonoids, besides phenolic and fatty acids, terpenoids, vitamins, amino acids, sugars, proteins, and minerals (BURDOCK, 1998; BANKOVA et al., 2000; ALMEIDA; MENEZES, 2002; BANKOVA et al., 2002; TORETI et al., 2013).

The benefits of propolis have been known for centuries and ancient people used this product for therapeutic purposes (CASTALDO; CAPASSO, 2002; PEREIRA et al., 2015). The composition of propolis is strongly associated to its geographical origin and vegetation found close to the hives (PEREIRA et al., 2002; CASTRO et al., 2007).

Thus, there is a worldwide diversity of propolis with different textures, aroma and colors that can vary from yellowish, greenish, reddish-brown, dark-brown tones to a black color (MARCUCCI, 1996; BURDOCK, 1998; ALENCAR et al., 2005; LOUREIRO, 2008; TORETI et al., 2013).

Because of its great biodiversity, the propolis produced in Brazil is classified in 13 different groups according to their physical-chemical and biological characteristics (PARK et al., 2000; ALENCAR et al., 2005; HAYACIBARA et al., 2005; DAUGSCH et al., 2008; BELMIRO et al., 2011). Among these groups, the green and red propolis are known all over the world and have been extensively researched. There is also a type of propolis called geopropolis found in South America, which peculiar characteristic is the fact that stingless bees incorporate soil when producing it (BARTH, 2006; SILVA et al., 2016).

Currently, propolis is known for having antimicrobial, antiviral, anticariogenic, anti-inflammatory, antioxidant, immunomodulatory, healing, and anesthetic properties, among other biological activities (FALCÃO et al., 2010; RIGHI et al., 2013; VALENZUELA-BARRA et al., 2015; ARAÚJO et al., 2016; CORRÊA et al., 2017; KUSTIAWAN et al., 2017; SILVA et al., 2017; VEIGA et al., 2017).

Received: Jul 19, 2019 Accepted: Nov 24, 2020

Associate Editor: Silvia Galleti

Peer Review History: Double-blind Peer Review. 
Besides its established use in Medicine and Pharmacology, studies have shown that propolis can be used in agriculture, especially in the control of crops phytopathogens, such as tomatoes (MORAES et al., 2011; PEREIRA et al., 2016), coffee (PEREIRA et al., 2013; 2016), beans (PEREIRA et al., 2014; 2016), cucumbers (PEREIRA et al., 2016), and grapes (MARINI et al., 2012; WUADEN et al., 2018). Its use in the agriculture is relatively recent and still requires further researches and the development of commercial products.

However, it is an alternative that can be applied in crop systems to avoid the indiscriminate use of pesticides that cause well-known damages to the environment and human beings. When considering natural products, sustainability and organic food, the use of propolis in agriculture becomes attractive, having the potential to be widely incorporated in the management of vegetable crops of economic importance in the near future (PEREIRA et al., 2008).

In agriculture, propolis is not used in its raw form, instead its compounds need to be extracted so that the final solution can be applied. Because of the complex chemical structure of propolis, some substances present in the raw form are soluble in water or alcohol or in both solvents (MELLO et al., 2010). At first, water was used to obtain the propolis extract. However, because it is practical and also due to the low solubility of some substances in water, currently the most used and effective solvent for the extraction process is the hydrous ethanol (KONISHI et al., 2004). The final product is the ethanolic extract of propolis.

Literature shows several different ways of preparing the ethanolic extract of propolis (EEP). In general, EEP is obtained by using $5-18 \%$ raw propolis in $70-90 \%$ hydrous ethanol. After resting for about five days, the solution is filtered through a paper filter and the final EEP is obtained. When used in agriculture, this extract is still diluted in distilled water in concentrations that vary from 0.1 to $10 \%$ EEP for later application. It is important to emphasize that each study employed different amounts of raw propolis and periods of time to obtain the EEP. This fact, along with different types of available propolis can cause variations on the effects observed in the studies. Therefore, future researches should be performed to investigate the full potential of using different types of propolis in crop management (PEREIRA et al., 2016).

Thus, this study carried out a literature review on the different aspects related to the use of propolis to manage agricultural crops and its advances in agriculture.

Investigations about propolis (EEP) and its benefits in the management of agricultural crops are recent. One of the most researched characteristics is its potential to control diseases of bacterial and fungal origin. There have been reports of the antagonistic effects of EEP on pathogens in some crops, such as eggplant (PASTANA et al., 2016), coffee (PEREIRA et al., 2013), beans (PEREIRA et al., 2014), mango (MACHADO et al., 2015), passion fruit (ZIBETTI et al., 2009), corn (SILVA et al., 2018), cucumber (PIVA, 2013), soybean (ZANATTO et al., 2018), and tomato (MORAES et al., 2011).

One of the pioneering studies in the control of bacteria investigated the use of a water-based extract of propolis in the in vitro control of Agrobacterium tumefaciens, Clavibacter michiganensis and Xanthomonas axonopodis pv. phaseoli (BIANCHINI; BEDENDO, 1998). The authors found an effective control of the bacteria using a $10 \%$ concentration of the extract. Although the researches related to propolis and its effect on bacteria and plant diseases are just in the initial stages, some of them have found in vitro the antagonistic effect of different propolis extracts in some Gram-positive and Gram-negative phytopathogenic bacteria, such as: A. tumefaciens, C. michiganensis, Erwinia chrysanthemi, X. axonopodis pv. phaseoli and Xanthomonas gardneri (BALDIN et al., 2014; LOUREIRO et al., 2014; PEREIRA et al., 2014; JASKI et al., 2015).

In these investigations, the main observed feature is the partial inhibition (bacteriostatic) of bacterial growth in the lab, showing that the EEP has the potential to be used as a tool to control some plant diseases. This activity is linked to the presence of flavonoids, aromatic acids and esters contained in propolis (BURDOCK, 1998). On the other hand, some bacteria in certain plants are apparently insensitive to commonly tested propolis extracts, such as the bacteria of the genus Pseudomonas (BIANCHINI; BEDENDO, 1998; HEIMBACH et al., 2016).

In addition to the bactericidal feature, there are some reports that evidenced the antagonistic action of EEP to phytopathogenic fungi. In the case of coffee crops, for instance, PEREIRA et al. $(2001 ; 2008)$ carried out lab and greenhouse experiments with EEP in the control of coffee rust (Hemileia vastatrix) and cercosporiosis (Cercospora coffeicolla) diseases. These authors concluded that the use of $4 \%$ EEP ( $16 \%$ raw propolis) could stop the germination of the fungi $H$. vastatrix, decreasing the incidence of rust to about $65 \%$. As for the cercosporiosis, its incidence decreased about $75 \%$ when applying the EEP. ANDROCIOLI et al. (2012) also observed a decrease in the incidence of coffee rust by using the EEP, finding out its efficacy was similar to the one obtained with commercial fungicides.

In bean crops, the use of EEP (10\% raw propolis) resulted in beneficial effects against the anthracnose, causing a $63 \%$ decrease in the progress curve of the disease (PEREIRA et al., 2014). Corroborating with the other studies, VIEIRA et al. (2011) also observed that the use of EEP in bean seeds reduced the in vitro growth of the fungi Alternaria spp., Aspergillus spp., Cladosporium spp. and Colletotrichum spp. 
As for the cucumber and tomato crops, when the studies were performed in a greenhouse, it was possible to notice that the use of $8 \%$ EEP (30\% raw propolis) resulted in a 53\% reduction in the progress curve of powdery mildew disease (Podosphaera fuliginea) in cucumbers and drastically reduced the severity of powdery mildew disease (Solanum lycopersicum) in tomatoes (MORAES et al., 2011; PIVA, 2013). In addition to powdery mildew, there are reports showing that the EEP was effective in the control of the fungus Alternaria solani, that causes the early blight disease in tomatoes (RUBIRA, 2008; MEINERZ et al., 2010).

Although recent, the use of propolis in the management of agricultural crops has been studied by different research groups, finding the antifungal capacity of EEP in several fungi, such as: Colletotrichum gloeosporioides, Corynespora cassiicola, Lasiodiplodia theobromae, Peronospora manshurica and Puccinia polysora (MONZOTE et al., 2012; MAEKAWA et al., 2013; MACHADO et al., 2015; PASTANA et al., 2016; SILVA et al., 2018; ZANATTO et al., 2018).

The efficacy of propolis on the control of some fungi and phytopathogenic diseases is possibly related to the formation of a waxy layer resulting from the application of EEP, which coats the leaves preventing the fungi penetration. Another possible characteristic is the elicit capacity of the phenolic compounds contained in the propolis that can stimulate the resistance of the plant to pathogens (PEREIRA et al., 2008).

Another property of propolis that has also been investigated is the postharvest conservation capacity of fruits and vegetables through the formation of a biodegradable biofilm. It is known that fruits and vegetables have low shelf life and that the postharvest technologies used to keep these foods for longer are desirable strategies, especially those alternatives that replace the use of synthetic products. In this sense, the use of propolis has a great potential because of its waxy and antimicrobial characteristics, avoiding the loss of moisture from food, reducing plant metabolism, delaying senescence and avoiding the presence of harmful microorganisms (KAMEYAMA et al., 2008; DAIUTO et al., 2012; ALI et al., 2014).

In order to evaluate the conservation potential of propolis, CUNHA et al. (2017) carried out a study and found out that when using $2.5 \%$ EEP ( $11 \%$ raw propolis) to coat the yellow passion fruit, there was a lower mass loss because the EEP reduced the water loss by transpiration and, consequently, a decrease in wilting, production and sensitivity to ethylene and oxidation reactions. DAIUTO et al. (2012) verified that in avocados, the use of $2 \%$ EEP along with the vegetable wax provided a lower mass loss, lower $\mathrm{CO}_{2}$ production and greater firmness compared to the fruits that were not coated with propolis. Furthermore, the authors evidenced that the use of propolis and wax in fruits makes their skin shine, providing a better visual aspect and increasing their commercialization. In another study that evaluated the papaya solo 'Golden' cultivar, PASSOS et al. (2016) found that $5 \%$ EEP (10\% raw propolis) had a positive effect on fruit firmness and prevented mass loss, having a conservation effect similar to the refrigerated treatment for eight days. This fact is important, because it is known that although refrigeration is a good practice of preserving papaya, it can cause injuries to the fruit because of the constant cold.

Thus, the EEP can be a viable alternative to keep fruits and vegetables fresh. Similarly, the researches with strawberry (LOEBLER et al., 2018) and grapes (PASTOR et al., 2011) report the preservation of fruits when the EEP was used as a coating, especially the reduction of mass loss and turbidity since the water loss was avoided. The preservation of food was also verified in lettuces (ARAUJO et al., 2012) when using the EEP as coating. The authors believe that propolis stopped the presence of microorganisms in the food, resulting in its preservation and increasing the shelf life.

Another property related to propolis is the beneficial effect on the vegetative growth of plants. However, this aspect requires further studies to clarify its mechanism of action. Currently, only few groups have researched this topic. Phytopathogen control was also the object of a study by PEREIRA et al. (2013), who observed increases of up to 74.75 and $23.76 \%$ in the coffee leaf area and number of leaves, respectively, when using 2.5\% EEP (4\% raw propolis). The authors associated this vegetative growth with the presence of nutrients in the composition of propolis.

The same effect on growth promotion was observed by PEREIRA et al. (2014) in beans cultivated in greenhouses, where the use of $4 \% \mathrm{EEP}$ ( $10 \%$ raw propolis) resulted in a $39 \%$ increase in productivity compared to the control. PEREIRA et al. (2018) verified an increase in magnesium and chlorophyll content in bean leaves and a $22 \%$ yield increase when $8 \%$ EEP (10\% raw propolis) was applied.

Propolis is an option in terms of natural product that has an evidenced action in the control of some phytopathogens in certain crops. Besides that, positive effects have been observed in the postharvest conservation of fruits and also mineral nutrition of the plant. The decrease in plant water stress is also an aspect to be researched when evaluating the use of EEP.

All reports regarding the use of propolis in agriculture are associated with in vitro and greenhouse experiments. There are strong indications for the practical use of propolis in the field and it can bring several benefits to agricultural crops. However, the advances must continue and, to become a reality, optimization in the process of obtaining the EEP in an industrial scale and the development of commercial products based on propolis aiming its specific use in agriculture are 
required. Despite the challenge involving the market and the entire production chain, studies show that propolis is a product with great potential to be used in agriculture in an efficient and sustainable way.

As mentioned above, studies involving the use of propolis in agriculture are scarce. Therefore, further studies are necessary, adding a larger number of crops and observing the consequent effects on them. In addition, the extracts should be standardized and the registration of commercial products should be possible, having a positive effect and avoiding the increase in the price of the production process.

\section{AUTHORS' CONTRIBUTIONS}

Conceptualization: Carvalho, G.J.L.; Sodré, G.S.; Formal analysis: Carvalho, G.J.L.; Literature search: Carvalho, G.J.L.; Sodré, G.S.;Supervision: Sodré, G.S.; Writing - original draft and Writing - review \& editing: Carvalho, G.J.L.; Sodré, G.S.

\section{AVAILABILITY OF DATA AND MATERIAL}

Data sharing not applicable to this article as no datasets were generated during the current study.

\section{FUNDING}

This work did not receive any specific grant from funding agencies in the public, commercial, or not-for-profit sectors.

\section{CONFLICTS OF INTEREST}

All authors declare that they have no conflict of interest.

\section{ETHICAL APPROVAL}

Not applicable.

\section{ACKNOWLEDGEMENTS}

Not applicable.

\section{REFERENCES}

ALENCAR, S.M.; AGUIAR, C.L.; PAREDES-GUZMÁN, J.; PARK, Y.K. Composição química de Baccharis dracunculifolia, fonte botânica das própolis dos estados de São Paulo e Minas Gerais. Ciência Rural, Santa Maria, v.35, n.4, p.909-915, 2005. https://doi.org/10.1590/ S0103-84782005000400025

ALI, A.; CHOW, W.L.; ZAHID, N.; ONG, M.K. Efficacy of propolis and cinnamon oil coating in controlling post-harvest anthracnose and quality of chilli (Capsicum annuum L.) during cold storage. Food and Bioprocess Technology, Dublin, v.7, n.9, p.2742-2748, 2014. https://doi.org/10.1007/s11947-013-1237-y

ALMEIDA, E.C.; MENEZES, H. Anti-inflammatory activity of propolis extracts: a review. Journal of Venomous Animals and Toxins, Botucatu, v.8, n.2, p.191-212, 2002. https://doi.org/10.1590/S0104-79302002000200002

ANDROCIOLI, H.G.; MENEZES JÚNIOR, A.O.; HOSHINO, A.T.; ANDROCIOLI, L.G. Produtos alternativos no controle da Hemileia vastatrix (Berkeley \& Broome) e Cercospora coffeicola (Berkeley \& Cooke) em cafeeiros. Coffee Science, Lavras, v.7, n.2, p.187-197, 2012. Available from: http://www.sbicafe.ufv.br/bitstream/handle/123456789/7915/Coffee\%20Science_v7_n2_p187-197_2012. pdf? sequence=1\&isAllowed=y. Access on: 4 Nov. 2020.

ARAUJO, Y.L.F.M.; SOUZA, C.O.; DRUZIAN, J.I.; PADILHA, F.F.; ORELLANA, S.C. Uso de biofilme de amido à base de própolis vermelha para a conservação de folhas de alface (Lactuca sativa). Scientia Plena, São Cristóvão, v.8, n.12(a), p.121002, 2012. Available from: https://www.scientiaplena.org.br/sp/article/view/1159. Access on: 4 Nov. 2020.

ARAÚJO, K.S.S; SANTOS JÚNIOR, J.F.; SATO, M.O.; FINCO, F.D.B.A.; SOARES, I.M.; BARBOSA; R.S.; ALVIM; T.C.; ASCÊNCIO, S.D.; MARIANO, S.M.B. Physicochemical properties and antioxidant capacity of propolis of stingless bees (Meliponinae) and Apis from two regions of Tocantins, Brazil. Acta Amazonica, Manaus, v.46, n.1, p.61-68, 2016. https://doi.org/10.1590/1809-4392201501045

BALDIN, D.; SCARIOT, E.; TELAXKA, F.J.; JASKI, J.M.; FRANZENER, G.; MOURA, G.S.; GROSSELLI, M.A. Indução de faseolina em feijão e na atividade antibacteriana sobre Xanthomonas axonopodis pv. phaseoli pelo extrato etanólico de própolis. Cadernos de Agroecologia, Pernambuco, v.9, n.1, p.1-5, 2014. Available from: http://revistas.aba-agroecologia.org.br/index.php/cad/article/view/15576. Access on: 4 Nov. 2020. 
BANKOVA, V.S.; CASTRO, S.L.; MARCUCCI, M.C. Propolis: recent advances in chemistry and plant origin. Apidologie, Champenoux, v.31, n.1, p.3-15, 2000. https://doi.org/10.1051/apido:2000102

BANKOVA, V.S.; POPOVA, M.; BOGDANOV, S.; SABATINI, A.-G. Chemical Composition of European Propolis: Expected and Unexpected Results. Zeitschrift für Naturforschung, Berlin, v.57, n.5-6, p.530-533, 2002. https://doi.org/10.1515/znc-2002-5-622

BARTH, O.M. Palynological analysis of geopropolis samples obtained from six species of Meliponinae in the Campus of the Universidade de Ribeirão Preto, USP, Brazil. Apiacta, v.41, n.2, p.71-85, 2006. Available from: https://www.apimondia.com/docs/apiacta/2006/barth_1. pdf. Access on: 4 Nov. 2020.

BELMIRO, M.S.; OKI, Y.; FERNANDES, G.W. Própolis: Nosso tesouro. APACAME - Mensagem Doce, São Paulo, v.112, p.9-12, 2011. Available from: https://www.apacame.org.br/mensagemdoce/112/artigo2.htm. Access on: 4 Nov. 2020.

BIANCHINI, L.; BEDENDO, I.P. Efeito antibiótico da própolis sobre bactérias fitopatogênicas. Scientia Agrícola, Piracicaba, v.55, n.1, p.149-152, 1998. https://doi.org/10.1590/S0103-90161998000100024

BONAMIGO, T.; CAMPOS, J.F.; ALFREDO, T.M.; BALESTIERI, J.B.P.; CARDOSO, C.A.L.; PAREDES-GAMERO, E.J.; SOUZA, K.P.; SANTOS, E.L. Antioxidant, Cytotoxic, and Toxic Activities of Propolis from Two Native Bess in Brazil: Scaptotrigona depilis and Melipona quadrifasciata anthiodioides. Oxidative Medicine and Cellular Longevity, Wisconsin, v.2017, p.1038153, 2017. https://doi. $\operatorname{org} / 10.1155 / 2017 / 1038153$

BURDOCK, G.A. Review of the biological properties and toxicity of bee propolis. Food and Chemical Toxicology, Reus, v.36, n.4, p. 347-363, 1998. https://doi.org/10.1016/S0278-6915(97)00145-2

CASTALDO, S.; CAPASSO, F. Propolis, an old remedy used in modern medicine. Fitoterapia, Novara, v.73, n.1, p.S1-S6, 2002. Supplementary 1. https://doi.org/10.1016/S0367-326X(02)00185-5

CASTRO, M.L.; CURY, J.A.; ROSALEN, P.L.; ALENCAR, S.M.; IKEGAKI, M.; DUARTE, S.; KOO, H. Própolis do sudeste e nordeste do Brasil: influência da sazonalidade na atividade antibacteriana e composição fenólica. Química Nova, São Paulo, v.30, N.7, p.1512-1516, 2007. https://doi.org/10.1590/S0100-40422007000700003

CORRÊA, F.R.S.; SCHANUEL, F.S.; MOURA-NUNES, N.; MONTE-ALTO-COSTA, A.; DALEPRANE, J.B. Brazilian red propolis improves cutaneous wound healing suppressing inflammation-associated transcription factor NFkB. Biomedicine \& Pharmacotherapy, South Carolina, v.86, p.162-171, 2017. https://doi.org/10.1016/j.biopha.2016.12.018

CUNHA, M.C.; PASSOS, F.R.; MENDES, F.Q.; SILVA, S.A.; ALMEIDA, W.L.; NASSER, V.G. Extrato de própolis na conservação pós-colheita de maracujá-amarelo. Interciência, Las Condes, v.42, n.5, p.320-323, 2017. Available from: https://www.interciencia.net/ wp-content/uploads/2017/08/320-5838-PASSOS-42-5.pdf. Access on: 4 Nov. 2020.

DAIUTO, É.R.; MINARELLI, P.H.; VIEITES, R.L.; ORSI, R.O. Propolis and vegetable wax in the conservation of Hass avocado. Semina: Ciências Agrárias, Londrina, v.33, n.4, p.1463-1474, 2012. https://doi.org/10.5433/1679-0359.2012v33n4p1463

DAUGSCH, A., MORAIS, C.S., FORT, P.; PARK, Y.K. Brazilian Red Propolis - Chemical Composition and Botanical Origin. Evidence-Based Complementary and Alternative Medicine, Oxford, v.5, n.4, p.435-441, 2008. https://doi.org/10.1093/ecam/nem057

FALCÃO, S.I.; VILAS-BOAS, M.; ESTEVINHO L.M.; BARROS, C.; DOMINGUES, M.R.M.; CARDOSO, S.M. Phenolic characterization of Northeast Portuguese propolis usual and unusual compounds. Analytical and Bioanalytical Chemistry, Heidelberg, v.396, n.2, p.887-897, 2010. https://doi.org/10.1007/s00216-009-3232-8

GHISALBERTI, E.L. Propolis: A Review. Bee World, v.60, n.2, p.59-84, 1979. https://doi.org/10.1080/0005772X.1979.11097738

HAYACIBARA, M.F.; KOO, H.; ROSALEN, P.L.; DUARTE, S.; FRANCO, E.M.; BOWEN, W.H.; IKEGAKI, M.; CURY, J.A. In vitro and vivo effects of isolated fractions of Brazilian propolis on caries development. Journal of Ethnopharmacology, Pretoria, v.101, n.1-3, p.110-115, 2005. https://doi.org/10.1016/j.jep.2005.04.001

HEIMBACH, N.S.; ÍTAVO, C.C.B.F.; LEAL, C.R.B.; ÍTAVO, L.C.V.; SILVA, J.A.; SILVA, P.C.G.; REZENDE, L.C.; GOMES, M.F.F. Resíduo da extração de própolis como inibidor bacteriano in vitro. Revista Brasileira de Saúde e Produção Animal, Salvador, v.17, n.1, p.65-72, 2016. https://doi.org/10.1590/S1519-99402016000100007

JASKI, J.M; FRANZENER, G.; MOURA, G.S.; SCHEFFER, D.C.; TELAXKA, F.J. Atividade Antimicrobiana de Extrato Etanólico de Própolis Verde sobre Fitobactérias do Feijoeiro. In: V SEMINÁRIO DE ENSINO, PESQUISA E EXTENSÃO (SEPE) V JORNADA DE INICIAÇÃO CIENTÍFICA SEMANA NACIONAL DE CIÊNCIA E TEC. Anais... Laranjeiras do Sul: Anais do SEPE - Seminário de Ensino, Pesquisa e Extensão da UFFS, 2015. Available from: https://portaleventos.uffs.edu.br/index.php/SEPE-UFFS/article/view/2431. Access on: 4 Nov. 2020. 
KAMEYAMA, O.; ABRÃO JÚNIOR, J.; TEIXEIRA, J.M.A.; ANDRADE, N.J.; MININ, V.P.R.; SOARES, L.S. Extrato de própolis na sanitização e conservação de cenoura. Revista Ceres, Viçosa, v.55, n.3, p.218-223, 2008. Available from: http://www.ceres.ufv.br/ojs/index. php/ceres/article/view/3307. Access on: 4 Nov. 2020.

KONISHI, S.; SAWAYA, A.C.H.F.; CUSTÓDIO, A.R.; CUNHA, I.B.S.; SHIMIZU, M.T. Análise da influência de agentes solubilizantes na atividade antimicrobiana de extratos de própolis e de uma formulação de spray hidroalcoólico. APACAME - Mensagem Doce, São Paulo, v.75, p.22-25, 2004. Available from: https://www.apacame.org.br/mensagemdoce/75/artigo.htm. Access on: 4 Nov. 2020.

KUSTIAWAN, P.M.; LIRDPRAPAMONGKOL, K.; PALAGA, T.; PUTHONG, S.; PHUWAPRAISIRISAN, P.; SVASTI, J.; CHANCHAO, C. Molecular mechanism of cardol, isolated from Trigona incisa stingless bee propolis, induced apoptosis in the SW620 human colorectal cancer cell line. BMC Pharmacology and Toxicology, Dayton, v.18, p.32, 2017. https://doi.org/10.1186/s40360-017-0139-4

LOEBLER, M.; SÁNCHEZ, C.; SANTOS, M.; VASILENKO, P.; DUARTE, M.P.; CRUZ, A.; GONÇALVES, M. Aplicação de extratos de própolis para conservação pós-colheita de morangos. Vida Rural, p.38-40, 2018.

LOUREIRO, E.M. Avaliação da qualidade da própolis produzida em Cáceres-MT. 2008. Dissertation (Masters in Environmental Sciences) - Universidade do Estado de Mato Grosso, Mato Grosso, 2008. Available from: http://portal.unemat.br/media/oldfiles/prppg/docs/79. Access on: 5 Nov. 2020.

LOUREIRO, E.M.; GALBIATI, C.; FRANZ, G.M.; MENDONÇA, J.C. Atividade antimicrobiana do mel e da própolis produzida por Apis melifera em apiários comerciais em Mato Grosso. In: $20^{\circ}$ CONGRESSO BRASILEIRO DE APICULTURA, $6^{\circ}$ CONGRESSO BRASILEIRO DE MELIPONICULTURA, EXPOAPI FEIRA DE NEGÓCIOS 2014: "SUSTENTABLIDADE, TECNOLOGIA E MERCADOS". Anais... Belém: CONBRAPI, 2014, p.16. Available from: http://www.semabelhasemalimento.com.br/wp-content/uploads/2015/03/ anais-conbrapi-2014.pdf. Access on: 5 Nov. 2020.

MACHADO, P.P.; VIEIRA, G.H.C.; MACHADO, R.A. Uso da própolis e óleo de nim no controle dos fungos Lasiodiplodia theobromae e Colletotrichum gloesporioides: principais patógenos que acometem os frutos da manga. Revista de Agricultura Neotropical, Cassilândia, v.2, n.4, p.31-37, 2015. https://doi.org/10.32404/rean.v2i4.653

MAEKAWA, L.E.; VALERA, M.C.; OLIVEIRA, L.D.; CARVALHO, C.A.T.; CAMARGO, C.H.R.; JORGE, A.O.C. Effect the Zingiber officinale and propolis on microorganism and endotoxins in root canals. Journal of Applied Oral Science, Bauru, v.21, n.1, p.25-31, 2013. https://doi.org/10.1590/1678-7757201302129

MARCUCCI, M.C. Propriedades biológicas e terapêuticas dos constituintes químicos da própolis. Química Nova, São Paulo, v.19, n.5, p.529536, 1996. Available from: http://static.sites.sbq.org.br/quimicanova.sbq.org.br/pdf/Vol19No5_529_v19_n5_12.pdf. Access on: 5 Nov. 2020.

MARINI, D.; MENSCH, R.; FREIBERGER, M.B.; DARTORA, J.; FRANZENER, G.; GARCIA, R.C.; STANGARLIN, J.R. Efeito antifúngico de extratos alcoólicos de própolis sobre patógenos da videira. Arquivos do Instituto Biológico, São Paulo, v.79, n.2, p.305-308, 2012. https:// doi.org/10.1590/S1808-16572012000200023

MEINERZ, C.C.; GHELLER, D.; TOLEDO, M.V.; MÜLLER, S.F.; STANGARLIN, J.R. Atividade de peroxidase na indução de resistência de tomateiro contra Alternaria solani por medicamentos homeopáticos. In: EAIC XIX ENCONTRO ANUAL DE INICIAÇÃO CIENTÍFICA. Anais... Guarapuava: UNICENTRO, 2010. Available from: https://anais.unicentro.br/xixeaic/pdf/2666.pdf. Access on: 5 Nov. 2020.

MELLO, B.C.B.S.; PETRUS, J.C.C.; HUBINGER, M.D. Desempenho do processo de concentração de extratos de própolis por nanofiltração. Food Science and Technology, Campinas, v.30, n.1, p.166-172, 2010. https://doi.org/10.1590/S0101-20612010000100025

MONZOTE, L.; CUESTA-RUBIO. O.; FERNANDEZ, M.C.; HERNANDEZ, I.M.; FRAGA, J.; PÉREZ, K.; KERSTENS, M.; MAES, L.; COS, P. In vitro antimicrobial assessment of Cuban propolis extracts. Memórias do Instituto Oswaldo Cruz, Rio de Janeiro, v.107, n.8, p.978-984, 2012. https://doi.org/10.1590/S0074-02762012000800003

MORAES, W.B.; JESUS JUNIOR, W.C.; BELAN, L.L.; PEIXOTO, L.A.; PEREIRA, A.J. Aplicação foliar de fungicidas e produtos alternativos reduz a severidade do oídio do tomateiro. Revista Nucleus, Ituverava, v.8, n.2, p.57-68, 2011. https://doi.org/10.3738/1982.2278.554

OLDONI, T.L.C.; CABRAL, I.S.R.; D’ARCE, M.A.B.R.; ROSALEN, P.L.; IKEGAKI, M.; NASCIMENTO, A.M.; ALENCAR, S.M. Isolation and analysis of bioactive isoflavonoids and chalcone from a new type of Brazilian propolis. Separation and Purification Technology, Leuven, v.77, n.2, p.208-213, 2011. https://doi.org/10.1016/j.seppur.2010.12.007

PARK, Y.K.; IKEGAKI, M.; ALENCAR, S.M. Classificação das Própolis Brasileira a Partir de suas Características Fisico-Químicas e Propriedades Biológicas. APACAME - Mensagem Doce, São Paulo, v.58, p.2-7, 2000. Available from: http://www.apacame.org.br/ mensagemdoce/58/artigo.htm. Access on: 5 Nov. 2020.

PASSOS, F.R.; MENDES, F.Q.; PINTO, M.C.E.; ARAÚJO, E.A.; CARVALHO, A.M.X. Propolis extract in postharvest conservation of Solo papaya cv. ‘Golden'. Semina: Ciências Agrárias, Londrina, v.37, n.6, p.4039-4050, 2016. https://doi.org/10.5433/1679-0359.2016v37n6p4039 
PASTANA, R.F.; VIEIRA, G.H.C.; MACHADO, P.P. Uso da própolis no controle "in vitro" do fungo Colletotrichum gloeosporioides causador da antracnose em berinjela. Revista de Agricultura Neotropical, Cassilândia, v.3, n.1, p.12-15, 2016. https://doi.org/10.32404/rean.v3i1.654

PASTOR, C.; SÁNCHEZ-GONZÁLES, L.; MARCILLA, A.; CHIRALT, A.; CHÁFER, M.; GONZÁLEZ-MARTÍNEZ, C. Quality and safety of table grapes coated with hydroxypropylmethylcellulose edible coatings containing propolis extract. Postharvest Biology and Technology, Leuven, v.60, n.1, p.64-70, 2011. https://doi.org/10.1016/j.postharvbio.2010.11.003

PEREIRA, A.S.; SEIXAS, F.R.M.S.; AQUINO NETO, F.R. Própolis: 100 anos de pesquisa e suas perspectivas. Química Nova, São Paulo, v.25, n.2, p.321-326, 2002. https://doi.org/10.1590/S0100-40422002000200021

PEREIRA, C.S.; ARAUJO, A.G.; GUIMARÃES, R.J.; PAIVA, L.C. Uso da própolis como inibidor da germinação de esporos de Hemileia vastatrix. APACAME - Mensagem Doce, São Paulo, v.64, p.22-24, 2001. Available from: https://www.apacame.org.br/mensagemdoce/64/ artigo.htm\#: :text=A\%20partir\%20da\%20concentra\%C3\%A7\%C3\%A3o\%20de,cafeicultura\%20e\%20tamb\%C3\%A9m\%20agricultura\%20 org\%C3\%A2nica. Access on: 5 Nov. 2020.

PEREIRA, C.S.; ASSIS, R.P.; ZANATO, I.B.; RIBEIRO, C.B.; ZAMBIAZZI, E.V. Application of ethanolic extract of propolis typified in nutrition and vegetative growth of beans. African Journal of Agricultural Research, Nigeria, v.13, n.1, p.21-26, 2018. https://doi.org/10.5897/ AJAR2017.12613

PEREIRA, C.S.; GUIMARÃES, R.J.; POZZA, E.A.; SILVA, A.A. Controle da cercosporiose e da ferrugem do cafeeiro com extrato etanólico de própolis. Revista Ceres, Viçosa, v.55, n.5, p.369-376, 2008. Available from: http://www.ceres.ufv.br/ojs/index.php/ceres/ article/view/3345. Access on: 5 Nov. 2020.

PEREIRA, C.S.; MAIA, L.F.P.; PAULA, F.S. Aplicação de extrato etanólico de própolis no crescimento e produtividade do feijoeiro comum. Revista Ceres, Viçosa, v.61, n.1, p.98-104, 2014. https://doi.org/10.1590/S0034-737X2014000100013

PEREIRA, C.S.; MATTE, W.D.; VENÂNCIO, P.H.B. Aplicação de extrato de própolis na agricultura. Revista de Ciências Agroambientais, Lisboa, v.14, n.1, p.143-156, 2016. Available from: https://periodicos.unemat.br/index.php/rcaa/article/view/1421. Access on: 11 Nov. 2020.

PEREIRA, C.S.; SOUZA, F.L.F.; GODOY, C.A. Extrato etanólico de própolis no controle da cercosporiose e no desenvolvimento de mudas de cafeeiro. Revista Brasileira de Agroecologia, Dois Vizinhos, v.8, n.1, p.170-178, 2013. Available from: http://revistas.aba-agroecologia. org.br/index.php/rbagroecologia/article/view/12872. Access on: 5 Nov. 2020.

PEREIRA, D.S.; FREITAS, C.I.A.; FREITAS, M.O.; MARACAJÁ, P.B.; SILVA, J.B.A.; SILVA, R.A.; SILVEIRA, D.C. Histórico e principais usos da própolis apícola. ACSA - Agropecuária Científica no Semi-Árido, Campina Grande, v.11, n.2, p.1-21, 2015. Available from: http:// revistas.ufcg.edu.br/acsa/index.php/ACSA/article/view/652. Access on: 5 Nov. 2020.

PIVA, C.A.G. Extratos de canola e própolis no controle de oídio em pepineiro. 2013. Dissertation (Master in Agronomy) - Universidade Tecnológica Federal do Paraná, Pato Branco, 2013. Available from: http://repositorio.utfpr.edu.br/jspui/bitstream/1/438/1/PB_PPGAG_M_Piva\%2c\%20 Claudia\%20Aparecida\%20Guginski_2013.pdf. Access on: 5 Nov. 2020.

RIGHI, A.A.; NEGRI, G.; SALATINO, A. Comparative Chemistry of Propolis from Eight Brazilian Localities. Evidence-Based Complementary and Alternative Medicine, Oxford, v.2013, p.267878, 2013. https://doi.org/10.1155/2013/267878

RUBIRA, J.C. Evaluación del efecto de extractos etanólicos de própolis sobre el control de Alternaria solani em cultivo ecológico de tomate (Solanum lycopersicum). 2008. Undergraduate thesis (Technical Agricultural Engineering, Agricultural Specialties) - Escola Superior d’Agricultura de Barcelona, Barcelona, 2008. Available from: https://core.ac.uk/download/pdf/41803476.pdf. Access on: 5 Nov. 2020.

SILVA, J.B.; COSTA, K.M.F.M.; COELHO, W.A.C.; PAIVA, K.A.R.; COSTA, G.A.V.; SALATINO, A.; FREITAS, C.I.A.; BATISTA, J.S. Quantificação de fenóis, flavonoides totais e atividades farmacológicas de geoprópolis de Plebeia aff. Flavocincta do Rio Grande do Norte. Pesquisa Veterinária Brasileira, Rio de Janeiro, v.36, n.9, p.874-880, 2016. https://doi.org/10.1590/s0100-736x2016000900014

SILVA, R.L.M.; DALMOLIN, V.R.F.; MARIANI, L.; MARTINS, L.P.; COSTA, M.J.N. Extrato etanólico de própolis no controle de ferrugem polissora (Puccinia polisora Underw.) na cultura do milho (Zea mays L.). Connectionline, Várzea Grande, n.18, p.1-15, 2018. https://doi. org/10.18312/1980-7341.n18.2018.826

SILVA, R.P.D.; MACHADO, B.A.S.; BARRETO, G.A.; COSTA, S.S.; ANDRADE, L.N.; AMARAL, R.G.; CARVALHO, A.A.; PADILHA, F.F.; BARBOSA, J.D.V.; UMSZA-GUEZ, M.A. Antioxidant, antimicrobial, antiparasitic, and cytotoxic properties of various Brazilian propolis extracts. PLoS ONE, San Francisco, v.12, n.3, p.e0172585, 2017. https://doi.org/10.1371/journal.pone.0172585

TORETI, V.C.; SATO, H.H.; PASTORE, G.M.; PARK, Y.K. Recent Progress of Propolis for Its Biological and Chemical Compositions and Its Botanical Origin. Evidence-Based Complementary and Alternative Medicine, Oxford, v.2013, p.697390, 2013. https://doi. org/10.1155/2013/697390 
VALENZUELA-BARRA, G.; CASTRO, C.; FIGUEROA, C.; BARRIGA, A.; SILVA, X.; HERAS, B.; HORTELANO, S.; DELPORTE, C. Anti-inflammatory activity and phenolic profile of propolis from two locations in Región Metropolitana de Santiago, Chile. Journal of Ethnopharmacology, Pretoria, v.168, p.37-44, 2015. https://doi.org/10.1016/j.jep.2015.03.050

VEIGA, R.S.; MENDONÇA, S. DE; MENDES, P.B.; PAULINO, N.; MIMICA, M.J.; LAGAREIRO NETTO, A.A.; LIRA, I.S.; LÓPEZ, B.G.-C.; NEGRÃO, V.; MARCUCCI, M.C. Artepillin C and phenolic compounds responsible for antimicrobial and antioxidant activity of green propolis and Baccharis dracunculifolia DC. Journal of Applied Microbiology, London, v.122, n.4, p.911-920, 2017. https://doi. $\operatorname{org} / 10.1111 /$ jam. 13400

VIEIRA, G.H.C.; DARDANI, P.; ANDRADE, W.P.; BARBOSA, C.A.F. 044 - Efeitos do extrato de própolis sobre a qualidade sanitária e fisiológica de sementes de feijão. Cadernos de Agroecologia, Pernambuco, v.5, n.1, p.1-4, 2011. Available from: http://revistas.aba-agroecologia. org.br/index.php/cad/article/view/10170. Access on: 5 Nov. 2020.

WUADEN, C.R.; GAIO, I.; SPERHACKE, T.; BARRO, J.P.; MILANESI, P.M. Atividade antifúngica do extrato alcoólico de própolis, álcool de cereais e do óleo essencial de manjericão sobre Botrytis cinerea. Colloquium Agrariae, Presidente Prudente, v.14, n.2, p.48-55, 2018. https://doi.org/10.5747/ca.2018.v14.n2.a205

ZANATTO, I.B.; BONALDO, S.M.; PEREIRA, C.S. Fungicidas e extrato etanólico de própolis no controle de doenças de final de ciclo da cultura da soja. Revista de Ciências Agrárias, Lisboa, v.41, n.1, p.165-174, 2018. https://doi.org/10.19084/RCA17062

ZIBETTI, A.P.; MOREIRA, F.C.; ABREU FILHO, B.A.; BONATO, C.M. Efeito de medicamentos homeopáticos em maracujazeiro (Passiflorae sp.) infectado por Xanthomonas campestris pv. passiflorae. In: V ENCONTRO INTERNACIONAL DE PRODUÇÃO CIENTÍFICA CESUMAR. Anais... Maringá: CESUMAR, 2009. Available from: https://docplayer.com.br/49599757-Efeito-de-medicamentoshomeopaticos-em-maracujazeiro-passiflorae-sp-infectado-por-xanthomonas-campestris-pv-passiflorae.html. Access on: 5 Nov. 2020. 